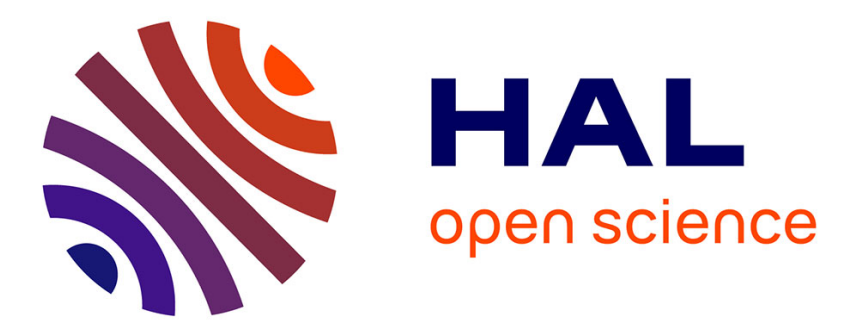

\title{
Maternal diversity patterns of Ibero-Atlantic populations reveal further complexity of Iberian honeybees
}

Maria Pinto, Dora Henriques, Margarida Neto, Helena Guedes, Irene Muñoz, João Azevedo, Pilar Rúa

\section{To cite this version:}

Maria Pinto, Dora Henriques, Margarida Neto, Helena Guedes, Irene Muñoz, et al.. Maternal diversity patterns of Ibero-Atlantic populations reveal further complexity of Iberian honeybees. Apidologie, 2013, 44 (4), pp.430-439. 10.1007/s13592-013-0192-y . hal-01201311

\section{HAL Id: hal-01201311 \\ https://hal.science/hal-01201311}

Submitted on 17 Sep 2015

HAL is a multi-disciplinary open access archive for the deposit and dissemination of scientific research documents, whether they are published or not. The documents may come from teaching and research institutions in France or abroad, or from public or private research centers.
L'archive ouverte pluridisciplinaire HAL, est destinée au dépôt et à la diffusion de documents scientifiques de niveau recherche, publiés ou non, émanant des établissements d'enseignement et de recherche français ou étrangers, des laboratoires publics ou privés. 


\title{
Maternal diversity patterns of Ibero-Atlantic populations reveal further complexity of Iberian honeybees
}

\author{
Maria Alice Pinto ${ }^{1}$, Dora Henriques ${ }^{1}$, Margarida Neto ${ }^{1}$, Helena Guedes ${ }^{1}$, \\ Irene MuÑoz ${ }^{2}$, João C. Azevedo ${ }^{1}$, Pilar de la Rúa ${ }^{2}$ \\ ${ }^{1}$ Mountain Research Centre (CIMO), Polytechnic Institute of Bragança, Campus de Sta. Apolónia, Apartado 1172, \\ 5301-855 Bragança, Portugal \\ ${ }^{2}$ Department of Zoology and Physical Anthropology, Faculty of Veterinary, Regional Campus of International \\ Excellence "Campus Mare Nostrum", University of Murcia, Murcia 30100, Spain
}

Received 2 July 2012 - Revised 19 November 2012 - Accepted 7 January 2013

\begin{abstract}
Dissecting complex diversity patterns typically exhibited by organisms of hybrid zones is among the greatest challenges in evolutionary biology. This has been a long-standing goal of numerous Iberian honeybee studies. Herein, we further contribute to this goal by a fine-scale maternal survey of the Portuguese honeybee populations. In addition to confirm a predicted African ancestry of Portuguese populations and negligible levels of $\mathrm{C}$-lineage introgression, our fine-scale survey revealed unparalleled levels of African maternal diversity and a remarkable north-south cline formed by African haplotypes of distinct ancestry. This survey further highlights the distinctiveness of Apis mellifera iberiensis by showing the existence of highly contrasting diversity patterns between the Atlantic and Mediterranean populations. Our findings further support an ancient natural invasion of the Iberian Peninsula possibly by Apis mellifera intermissa and also by Apis mellifera sahariensis. Protecting this African legacy is of unquestionable importance, especially with Iberia becoming warmer and dryer.
\end{abstract}

\section{Apis mellifera iberiensis / genetic diversity / mtDNA / DraI test / Portugal}

\section{INTRODUCTION}

Honeybee diversity has been extensively surveyed across its wide distributional range in Africa, Europe, and the Middle East using a multitude of markers ranging from the early morphological studies (Ruttner 1988) to the more recent analysis of single nucleotide polymorphisms (Whitfield et al. 2006). These surveys have provided a largely concordant grouping of

Electronic supplementary material The online version of this article (doi:10.1007/s13592-013-0192-y) contains supplementary material, which is available to authorized users.

Corresponding author: M.A. Pinto, apinto@ipb.pt

Manuscript editor: Marina Meixner diversity into four major evolutionary lineages, whose designations are roughly coincident with their geographical ranges, namely: the African (A), the Middle Eastern $(\mathrm{O})$, the eastern European $(\mathrm{C})$, and the western European (M). Current distribution of these lineages is largely parapatric with contact zones identified in Italy (Franck et al. 2000), Turkey (Kandemir et al. 2006), Libya (Shaibi et al. 2009a), and in the Iberian Peninsula (Smith et al. 1991; Franck et al. 1998; Garnery et al. 1998; Arias et al. 2006; Miguel et al. 2007; Cánovas et al. 2008). Special attention has been paid to the Iberian contact zone, which has been examined with biparental and, more extensively, with maternal markers (Smith et al. 1991; Franck et al. 1998; Garnery et al. 1998; Arias et al. 2006; Miguel et al. 2007, 2011; Cánovas et al. 2008, 2011). 
The Iberian contact zone, formed by lineage A in the south and $\mathrm{M}$ in the north, was first reported by RFLP analysis of the entire mtDNA molecule in samples collected across the Mediterranean coast of Spain (Smith et al. 1991). Since then, multiple surveys of Spanish populations, particularly with the popular DraI test (Garnery et al. 1993), not only confirmed and refined the shape of the cline but also revealed that Iberian diversity patterns were in fact more complex than anticipated earlier (Franck et al. 1998; Garnery et al. 1998; De la Rúa et al. 2002; Miguel et al. 2007; Cánovas et al. 2008). Indeed, there are more haplotypes of lineage A and M ancestry in the Iberian Peninsula than in the remaining extensive territory where both lineages occur (Franck et al. 1998, 2001; Miguel et al. 2007; Cánovas et al. 2008; Pinto et al. 2012). While this observation has supported a consensual view of an Iberian glacial refuge for the $\mathrm{M}$ lineage (Miguel et al. 2007), the origin of African-derived patterns exhibited by Iberian honeybees is hotly debated (Franck et al. 1998; Cánovas et al. 2008).

Despite a shared African maternal ancestry, Iberian honeybees are highly differentiated from their African counterparts (Garnery et al. 1995; Franck et al. 1998, 2001). Northern African populations are dominated by haplotypes of sublineage $\mathrm{A}_{\text {II }}$ ancestry, whereas Iberian populations harbor predominantly sub-lineage $\mathrm{A}_{\mathrm{I}}$ haplotypes, although haplotypes $\mathrm{A}_{\text {II }}$ are also present but at low frequencies (Franck et al. 2001; Cánovas et al. 2008). However, contrasting with sub-Saharan African populations, similarly dominated by $A_{I}$ haplotypes, the most abundant $A_{I}$ haplotype (A2) in the Iberian Peninsula is rarely found in the African continent (Franck et al. 2001; Cánovas et al. 2008). To complicate matters further, northern IberoAtlantic populations descend from sub-lineage $\mathrm{A}_{\text {III }}$, which is virtually absent in the African continent (Franck et al. 1998, 2001), but frequently observed in the Atlantic archipelagos (De la Rúa et al. 1998, 2001a, 2006). In summary, the Iberian Peninsula has seemingly been a stage for extensive interaction among honeybees of multiple origins.

While honeybee diversity patterns of the Mediterranean-influenced Iberian territory have been thoroughly documented, the Atlantic side has remained largely undersampled. To fill the gap, we performed a fine-scale maternal survey of Portuguese populations. The results presented here show a strong north-south partitioning of sub-lineage $A_{\text {III }}$ and sub-lineage $A_{I}$ haplotypes suggesting that maternal composition of IberoAtlantic populations is distinct from that of the Ibero-Mediterranean populations. This remarkable differentiation and unique variation indicate that the Atlantic side of the Iberian Peninsula is an important reservoir of Apis mellifera iberiensis diversity.

\section{MATERIALS AND METHODS}

\subsection{Samples and DNA extraction}

Between 2008 and 2010, adult honeybee workers were sampled from 786 apiaries, located in every district of continental Portugal, and grouped into 18 populations (Table I and Figure 1). Samples were transported to the laboratory in absolute ethanol and stored at $-20^{\circ} \mathrm{C}$ until molecular analysis. Each analyzed individual represents a single colony and apiary.

\subsection{Molecular analysis}

Total DNA was extracted from one leg using a $10 \%$ Chelex ${ }^{\circledR}$ protocol (Walsh et al. 1991). Haplotypes were identified using the DraI test (Garnery et al. 1993), which consists on the PCR amplification of the intergenic tRNA ${ }^{\text {leu }}$-cox 2 region followed by digestion with the enzyme DraI (Promega ${ }^{\circledR}$ ). Amplification was performed using the primers E2 and $\mathrm{H} 2$ and the PCR reaction and conditions detailed by Garnery et al. (1993), with minor modifications. PCR products were digested with $\mathrm{DraI}$, following manufacturer's recommendations, and then separated and sized on a $4 \%$ wide range/standard 3:1 agarose gel (Sigma-Aldrich ${ }^{\circledR}$ ). The band patterns were examined and the haplotypes were identified following the complete set of restriction maps and restriction fragment sizes reported to date (Franck et al. 2001; De la Rúa et al. 2005; Collet et al. 2006; Pinto et al. 2012). Each haplotype was assigned to a lineage or to an African sub-lineage, as determined by absence of the $\mathrm{P}$ element (lineage $\mathrm{C}$ ), the form of the $\mathrm{P}$ element ( $\mathrm{P}$ in lineage $\mathrm{M} ; \mathrm{P}_{0}$ in sub-lineages $\mathrm{A}_{\mathrm{I}}$ and $\mathrm{A}_{\mathrm{II}} ; \mathrm{P}_{1}$ in sublineage $\mathrm{A}_{\text {III }}$ ), DraI cut sites, and the number of repeats 


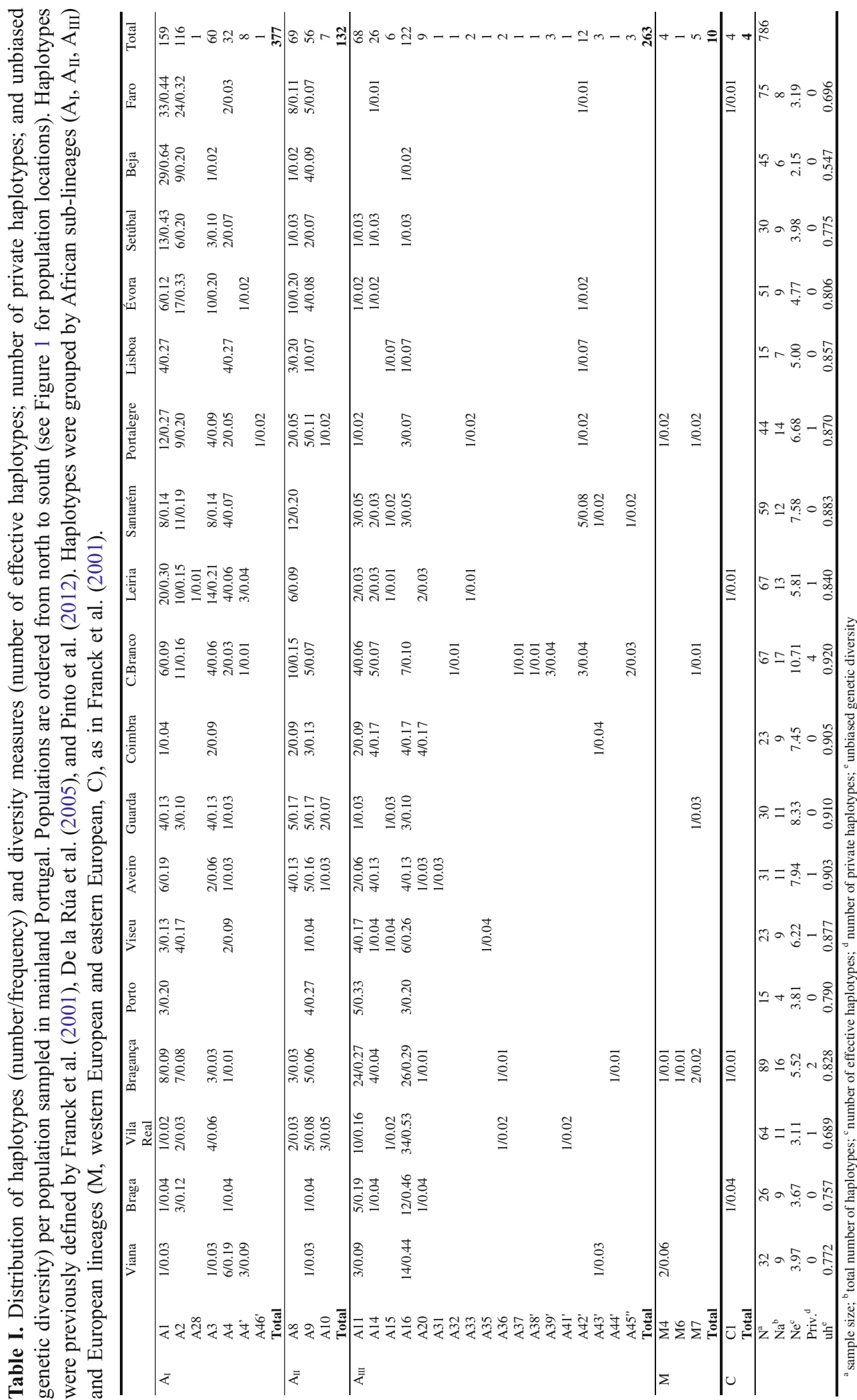



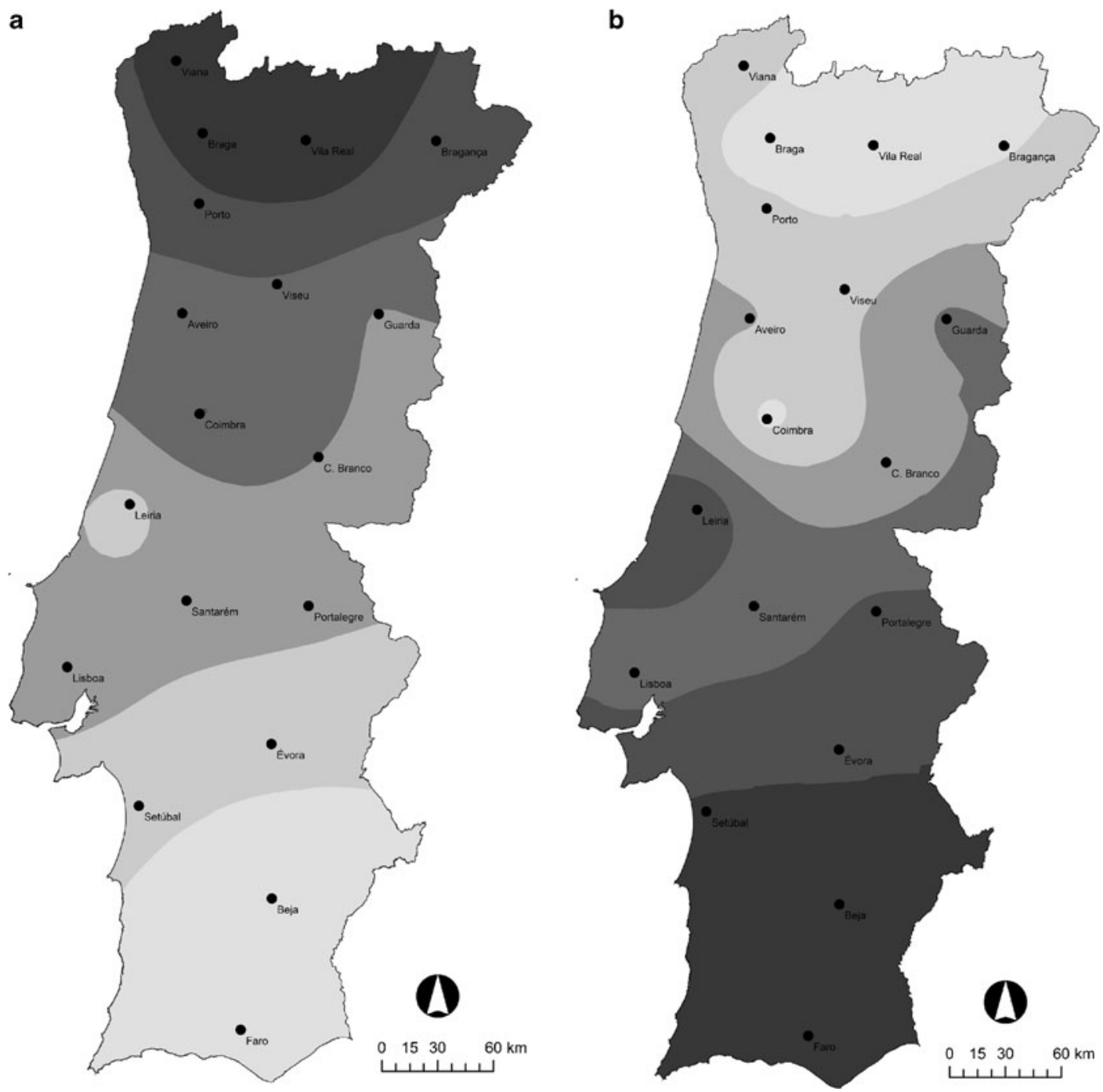

Figure 1. Synthetic map of Portugal illustrating geographic pattern of genetic diversity obtained from MDS analysis. The map was generated by interpolating the first dimension of MDS analysis using $F_{\mathrm{ST}}$ values obtained with haplotypic frequency data (a) and lineages and sub-lineage frequency data (b). In (a), darker tones represent lower values of dimension 1 axis of the MDS analysis, whereas in (b), they represent higher values. Dots indicate the centroid of each sampled population.

of the Q element (Garnery et al. 1993; De la Rúa et al. 1998; Franck et al. 1998, 2001; Rortais et al. 2011; Pinto et al. 2012).

\subsection{Data analysis}

Diversity measures were obtained with GenAlEx 6.4 (Peakall and Smouse 2006) and $F_{\text {ST }}$ values with
Arlequin 3.5.1.2 (Excoffier et al. 2005), with significance tested by 10,100 permutations. $F_{\mathrm{ST}}$ matrix was summarized in two major dimensions using multidimensional scaling (MDS) analysis, as implemented by Statistica 7.0 (StatSoft, Inc. [Tulsa, OK] 1999). Using the centroid of the sampled areas as the geographic coordinates for each of the 18 locations, the values obtained in the first MDS dimension were 
spatially interpolated through ordinary kriging, based on an omnidirectional spherical variogram model, to generate a synthetic map. Kriging was preceded by variography to analyze and explore the spatial autocorrelation of the variables, model parameterization, and error analysis. The relationships among the African haplotypes were established using the reduced medianmedian joining (RM-MJ) approach (Bandelt et al. 1999) implemented in Network 4.6.1.0 (Fluxus Engineering, Clare, UK; http://www.fluxus-engineering.com). A binary matrix was built using 16 characters including presence/absence of $\mathrm{P}_{1}$ and $\mathrm{Q}$ elements, large indels $(>11 \mathrm{bp}$ ), and DraI cut sites. The network was constructed using the following settings: $r=2, \varepsilon=10$, the $\mathrm{P}_{1}$ element was upweighted, and the two most variables characters were downweighted. Where applicable, statistical significance levels were adjusted for multiple comparisons using the sequential Bonferroni procedure to correct for type I error (Rice 1989).

\section{RESULTS}

A total of 32 haplotypes were observed among the 786 colonies sampled in this study (Table I). As expected, most (28) haplotypes were of African ancestry. Only three haplotypes (M4, M6, M7) belonged to the western European lineage and one $(\mathrm{C} 1)$ to the eastern European. The frequency distribution of the 32 haplotypes shows that $98 \%$ (772) of the colonies were of African ancestry being A1 the most common and widespread haplotype (159 colonies, $20.2 \%$ ). Over $50.5 \%$ (397) of the African colonies carried only three haplotypes: A1 (159 colonies, $20.2 \%)$, A16 (122 colonies, $15.5 \%$ ), and A2 (116 colonies, $14.8 \%$ ). Most haplotypes (25) exhibited frequencies lower than $5 \%$. Among those were the $\mathrm{M}$ and $\mathrm{C}$-lineage haplotypes with frequencies of $1.3 \%$ (10 colonies) and $0.5 \%$ (four colonies), respectively (Table I).

Haplotype distribution per population revealed a dramatic change in maternal composition from north to south (Table I). Haplotypes A16 and A11 (sub-lineage $\mathrm{A}_{\text {III }}$ ) were the most frequent in the northernmost populations (e.g., Viana, Braga, Vila Real, Bragança). However, they were virtually absent in the southern populations (e.g., Évora, Setúbal, Beja, Faro) where A1 and A2 (sub-lineage $A_{I}$ ) become dominant. Non-African haplotypes were present at very low frequencies in only eight populations, mostly located in the northern half of the country. Bragança was the location with the greatest number of non-African haplotypes with one sample carrying an eastern European haplotype (C1) and four samples carrying three western European (one M4, one M6, two M7).

The diversity measures (Table I) showed that the population of Castelo (C.) Branco, located in the center inland of Portugal (Figure 1), exhibited the greatest number of haplotypes (17 total, 11 effective, and 4 private) and the highest genetic diversity (0.92). The least diverse population $(0.55)$ was located in the south (Beja) with only two effective haplotypes and none private. The $F_{\text {ST }}$ values (Online resource 1 ) revealed that the highest differentiation was observed between Vila Real and Beja $(0.359, P<0.000)$ and the lowest between the population pairs of Bragança/Viseu, Portalegre/Setubal, and Braga/Vila Real $(0.007, P$ $>0.05)$, respectively. The geographical pattern of genetic differentiation, represented in the synthetic map (Figure 1a), shows a north-south gradient that peaks in the south with the populations of Beja and Faro standing out as the most differentiated (clearest shade).

An RM-MJ network revealed a highly complex distribution of haplotypes forming two main groups (Figure 2). The more complex right-hand side group is composed of sublineage $\mathrm{A}_{\text {III }}$ haplotypes being A16 and A11 the most interior ones. The left-hand side joins haplotypes belonging to both sub-lineages $A_{I}$ and $A_{I I}$. Sub-lineage $A_{I I}$ haplotypes form a group which is connected to A2. Except for A28 and A46', all singletons are of sub-lineage $\mathrm{A}_{\text {III }}$ ancestry.

The frequency distribution of the African haplotypes grouped by sub-lineage (Table I) revealed that $A_{I}$ was the most frequent with $49 \%(377)$ of the colonies, followed by $\mathrm{A}_{\text {III }}$ with $38 \%$ (263). Sub-lineage $A_{\text {II }}$ was detected in only $17 \%$ (132) of the colonies. The geographical distribution of sub-lineages (Table I) shows a sharp north-south trend. The 


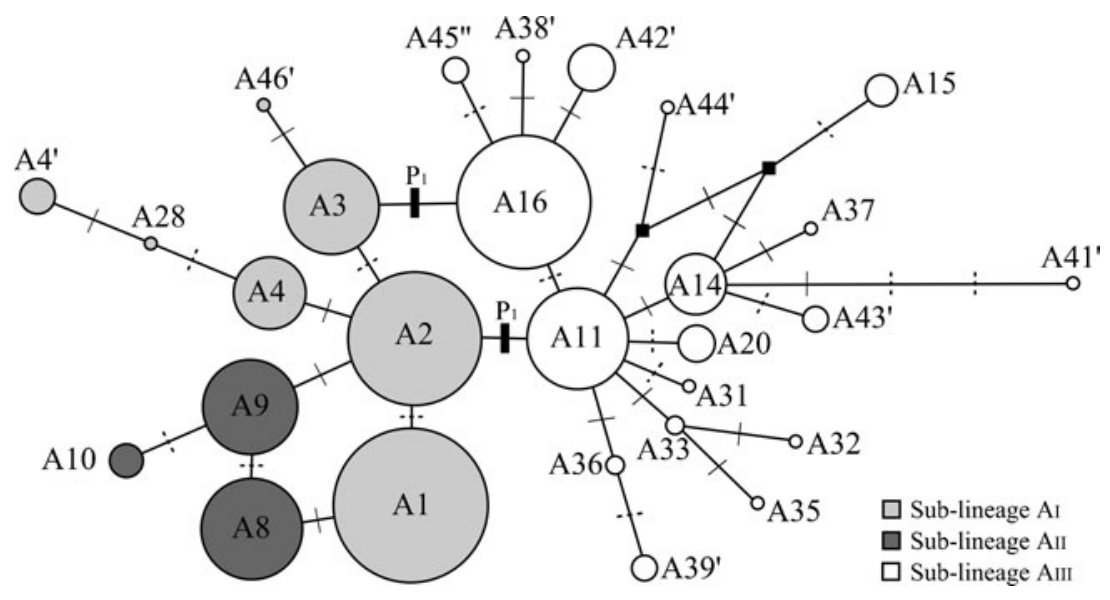

Figure 2. RM-MJ network relating the PCR-RFLP characters of the tRNA ${ }^{\text {leu }}$-cox 2 intergenic region observed in populations sampled in mainland Portugal. Haplotypes were previously defined by Franck et al. (2001), De la Rúa et al. (2005), and Pinto et al. (2012). Hypothetical (unsampled or extinct) haplotypes are symbolized as filled squares. The cross lines along branches represent mutational steps between nodes (dashed lines are indels, whereas full lines are losses/gains of $\mathrm{DraI}$ cut site). The sizes of the circles size are proportional to the haplotype frequencies. The different tones represent African sub-lineages, as defined by Franck et al. (2001).

Atlantic sub-lineage $\mathrm{A}_{\text {III }}$ was predominant in the northern populations contrasting with those from the south where colonies were mostly of sub-lineage $A_{I}$ ancestry. Sub-lineage $A_{I I}$ was present everywhere, but at residual levels in some northern populations. The $F_{\mathrm{ST}}$ values obtained with data grouped by lineage and sub-lineage were much higher (Online resource 1), but similarly to the previous comparisons Beja was the most differentiated population. The synthetic map reveals again a strong northsouth structure (Figure 1b). In accordance with Figure 1a, the population of Leiria is genetically closer to the southern populations. The demarcation of Coimbra from the more inland populations of $\mathrm{C}$. Branco and Guarda is roughly coincident with the highest Portuguese mountain range.

\section{DISCUSSION}

This fine-scale maternal survey of Portuguese populations enabled a refinement of the Iberian cline reported by previous studies (Smith et al. 1991; Garnery et al. 1995, 1998; Franck et al. 1998; Arias et al. 2006; Miguel et al. 2007,
2011; Cánovas et al. 2008). As expected from the clinal pattern documented in those studies, most Portuguese populations were nearly pure African $(98.2 \%)$. Only $1.3 \%$ of the colonies harbored a haplotype of lineage $\mathrm{M}$ ancestry. The spatial representation of this variation shows a well-defined north-south gradient (Figure 1a, b) suggesting that contemporary human-assisted dispersal (through, for example, queen trading and migratory beekeeping) has had a negligible impact on population sub-structure in Portugal. Similarly to Spanish populations (Franck et al. 1998; De la Rúa et al. 2005; Miguel et al. 2007), Portuguese populations harbor a low frequency of $\mathrm{C}$-lineage haplotypes reflecting beekeeper's preference for local honeybees.

Two hypotheses have been proposed for the origin of the Iberian contact zone: ancient multiple range expansions (Cánovas et al. 2008) and human-mediated introductions during Muslim invasions (Franck et al. 1998). Iberian honeybees exhibit unparalleled patterns of maternal diversity (further magnified by the unique composition of the Atlantic populations) and are profoundly differentiated from northern African populations. Contrasting with northern African 
populations, which harbor mostly A8 and A9 haplotypes (Garnery et al. 1995; Franck et al. 2001), Portuguese populations are dominated by A1, A16, and A2 haplotypes and Spanish by A2, A1, and A3 (Cánovas et al. 2008). Haplotypes A8 and A9 are present in Portugal and Spain, although at low frequencies, and A2, $\mathrm{A} 3$, and A16 are rare or have not been sampled in North Africa (Garnery et al. 1995; Franck et al. 2001). Accordingly, the high levels of diversity and complexity of Iberian honeybees revealed in this and other studies, together with the profound differentiation from northern African populations (Garnery et al. 1995; Franck et al. 1998, 2001), are more compatible with the hypothesis of ancient invasions from Africa.

Regardless the timing or mode of expansion into Iberia, Apis mellifera intermissa has been assumed as the source of African genes in A. m. iberiensis (Smith et al. 1991). However, given the complex Iberian patterns and profound divergence between both subspecies, it is possible that multiple expansion waves of multiple origins might have occurred long time ago. We speculate that a component of the variation that we see today in A. $m$. iberiensis has its roots in an ancient expansion of Apis mellifera sahariensis. This subspecies may have been formerly distributed in a much wider area (Ruttner 1988), a hypothesis that is supported by a recent morphometric study that found more similarities between Libyan honeybees and $A$. $m$. sahariensis than with the geographically closer Apis mellifera lamarckii and A. m. intermissa (Shaibi et al. 2009b), although sequencing data of the tRNA ${ }^{\text {leu }}$-cox 2 intergenic region identified those populations as being mostly of $\mathrm{O}$ lineage ancestry (Shaibi et al. 2009a).

While morphometry recognizes $A$. $m$. sahariensis as a distinct unit (Ruttner 1988), the tRNA $^{\text {leu }}$-cox2 intergenic region does not produce subspecies-specific haplotypes (Franck et al. 2001). Nonetheless, haplotypic frequency distributions vary between $A$. m. intermissa and $A . m$. sahariensis (Franck et al. 2001), providing some level of maternal differentiation. Haplotype A1, for example, is rare in northern Moroccan populations of $A$. m. intermissa and highly frequent in the more southern populations of $A$. m. sahariensis (Garnery et al. 1995; Franck et al. 2001). The A1 trend was confirmed by another study (De la Rúa et al. 2007), which also reported the presence of haplotype A15 in a coastal Moroccan population of $A . m$. sahariensis. This was an interesting finding, as A15 and A1 are among the most prevalent haplotypes in Canaries and Madeira, further reinforcing the hypothesis of an ancient colonization from Africa into both archipelagos (De la Rúa et al. 1998, 2001a, 2006). Moreover, it suggests that sub-lineage $\mathrm{A}_{\text {III }}$ haplotypes might be a relic of a period that predates contraction of $A . m$. sahariensis. Alternatively, sub-lineage $\mathrm{A}_{\mathrm{III}}$ evolved in the Atlantic coast of the Iberian Peninsula and has been introduced elsewhere by humans. While this is a plausible hypothesis, the high frequency of haplotype A1 in Portugal (Table I) is better explained by an African source population alternative to $A$. $m$. intermissa. Another compelling indication of a possible ancient invasion by $A . m$. sahariensis is provided by sequence data of an mtDNA coding region (Arias and Sheppard 1996). Interestingly, in this phylogenetic study, the sequences of $A . m$. iberiensis (collected in Portugal) were more identical to A. m. sahariensis than to $A$. m. intermissa.

The fact that $A . m$. sahariensis is now a relic subspecies (Ruttner 1988) complicates reconstruction of a putative invasion of the Iberian Peninsula. Whether sub-lineage $A_{\text {III }}$ haplotypes were abundant in the Atlantic coast of Africa and preferentially occupied the Atlantic coast of the Iberian Peninsula during a range expansion is uncertain. Whether haplotype A2 was abundant in North Africa and was introduced into the Iberian Peninsula during a colonization wave that favored a Mediterranean route is also uncertain. Haplotype A 2 is by far the most abundant and widespread haplotype in Spain (Franck et al. 1998; Miguel et al. 2007; Cánovas et al. 2008). It is also common in mainland Portugal and in the Mediterranean islands of Ibiza (De la Rúa et al. 2001b) and Sicily (Franck et al. 2001). In the remaining territory, it is rare and exhibits a disjunct distribution. It has been reported at low frequencies on Madeira (De la Rúa et al. 2006), Southern Morocco (Franck et al. 2001), Algeria (Chahbar et al. 2012), 
and as far as Syria (Alburaki et al. 2011). While A2 current distribution could lead to the assumption of an Iberian Mediterranean origin and ensuing human-assisted introduction elsewhere, its central position in the network and multiple connections with the other haplotypes (Figure 2) indicate that A2 is an old haplotype. Therefore, it is more likely that $\mathrm{A} 2$ arrived at the Iberian Peninsula a long time ago and current low frequency and disjunct distribution in Africa and Middle East resulted from a contraction process, although some level of human-assisted introduction cannot be excluded.

This study shows that diversity patterns exhibited by Ibero-Atlantic honeybee populations are very distinct from their Ibero-Mediterranean and African counterparts. It is a remarkable fact that in this corner of the extensive area occupied by the African lineage, three well-represented sublineages came together with two of them $\left(\mathrm{A}_{\mathrm{III}}\right.$ and $A_{I}$ ) forming a stepped north-south gradient. While the encounter of genetically different populations would yield a pattern consistent with a stepped gradient, it is expectable that the high dispersal abilities and gene flow typical of honeybees would rapidly erase the signal of such historical event, especially at this small geographical scale. The alternative explanation for the observed cline is selection. Mitochondrial DNA has long been considered a neutral molecule. However, evidence is accumulating that it is subject to selection pressures (reviewed by Rand 2001; Ballard and Whitlock 2004). In honeybees, selection has been invoked to explain maintenance of the cline formed by western European and African lineages in the Iberian Peninsula (Franck et al. 1998; Cánovas et al. 2008) and the loss of European haplotypes in Africanized honeybee populations due to negative heterosis in hybrids (reviewed by Schneider et al. 2004). Although we do not have empirical support or indirect evidence from sequence variation analyses, we suggest that selection might have had a major role in shaping the observed IberoAtlantic well-defined maternal cline, a hypothesis that certainly deserves further attention.

Above we postulate that haplotypes of sublineage $A_{I I I}$ ancestry arrived in the Iberian Peninsula through an ancient range expansion from Africa. However, given the high number of sub-lineage $A_{\text {III }}$ haplotypes, which have only been reported for Portugal, we cannot exclude the hypothesis that diversification might have occurred in Iberia following colonization. Considering the high mutation rate for the tRNA ${ }^{\text {leu }}$-cox2 intergenic region, especially for sequences with more than two Q elements (Franck et al. 1998), and assuming a long time since African invasion, this is a plausible scenario. This study suggests that the Atlantic side of the Iberian Peninsula has been a place of contact of haplotypes of multiple origins and possibly a place of maternal diversification. Therefore, we may claim that the Atlantic side of the Iberian Peninsula has not only been a melting pot, but also a hotspot of African maternal diversity. Protecting this legacy that was left from a past history shared with Africa is of unquestionable importance, especially in a context of rapid environmental change with the Iberian Peninsula turning warmer and dryer.

\section{ACKNOWLEDGMENTS}

We are profoundly grateful to numerous collaborators of the Divisões de Intervenção Veterinária (Direcção Geral de Alimentação e Veterinária), Laboratórios de Patologia Apícola, and Associações de Apicultores, who kindly provided the samples. Thanks are also owed to Miguel Vaz-Pinto for GIS assistance and Larissa Souza for helping with DNA extractions. Two referees and the editor Marina Meixner made useful comments. Financial support was provided by Fundação para a Ciência $e$ Tecnologia and COMPETE/QREN/EU (project PTDC/BIA-BEC/099640/2008), Programa Apícola Nacional (Medida 6A) to M. A. Pinto, and by Fundación Séneca (project 11961/PI/09) to P. De la Rúa. I. Muñoz is supported by the Ministry of Education, Culture and Sports.

Les profils de la diversité maternelle des populations ibéro-atlantiques révèlent une importante complexité des abeilles ibériques

Apis mellifera iberiensis/diversité génétique/ ADNmitochondrial/test DraI/Portugal 
Muster in der maternalen Diversität in den iberoatlantischen Populationen weisen auf weitere Komplexität der Iberischen Honigbienen hin

\section{Apis mellifera iberiensis/genetische Diversität/mtDNA/ DraI Test/Portugal}

\section{REFERENCES}

Alburaki, M., Moulin, S., Legout, H., Alburaki, A., Garnery, L. (2011) Mitochondrial structure of Eastern honeybee populations from Syria, Lebanon and Iraq. Apidologie 42, 628-641

Arias, M.C., Sheppard, W.S. (1996) Molecular phylogenetics of honey bee subspecies (Apis mellifera L.) inferred from mitochondrial DNA sequence. Mol. Phylogenet. Evol. 5, 557-566

Arias, M.C., Rinderer, T.E., Sheppard, W.S. (2006) Further characterization of honey bees from the Iberian Peninsula by allozyme, morphometric and mtDNA haplotype analyses. J. Apic. Res. 45, 188196

Ballard, J.W.O., Whitlock, M.C. (2004) The incomplete natural history of mitochondria. Mol. Ecol. 13, 729-744

Bandelt, H.J., Forster, P., Rohl, A. (1999) Medianjoining networks for inferring intraspecific phylogenies. Mol. Biol. Evol. 16, 37-48

Cánovas, F., De la Rúa, P., Serrano, J., Galián, J. (2008) Geographical patterns of mitochondrial DNA variation in Apis mellifera iberiensis (Hymenoptera: Apidae). J. Zool. Syst. Evol. Res. 46, 24-30

Cánovas, F., De la Rúa, P., Serrano, J., Galián, J. (2011) Microsatellite variability reveals beekeeping influences on Iberian honeybee populations. Apidologie 42, 235-251

Chahbar, N., Muñoz, I., Dall'Olio, R., De la Rúa, P., Serrano, J., Sallaheddine, D. (2012) Population structure of North African honey bees is influenced by both biological and anthropogenic factors. J. Insect Conserv. doi:10.1007/s10841-012-9520-1

Collet, T., Ferreira, K.M., Arias, M.C., Soares, A.E.E., Del Lama, M.A. (2006) Genetic structure of Africanized honeybee populations (Apis mellifera L.) from Brazil and Uruguay viewed through mitochondrial DNA COI-COII patterns. Heredity 97, 329-335

De la Rúa, P., Serrano, J., Galián, J. (1998) Mitochondrial DNA variability in the Canary islands honeybees (Apis mellifera L.). Mol. Ecol. 7, 15431547

De la Rúa, P., Galián, J., Serrano, J., Moritz, R.F.A. (2001a) Genetic structure and distinctness of Apis mellifera L. populations from the Canary Islands. Mol. Ecol. 10, 1733-1742
De la Rúa, P., Galián, J., Serrano, J., Moritz, R.F.A. (2001b) Molecular characterization and population structure of the honeybees from the Balearic islands (Spain). Apidologie 32, 417-427

De la Rúa, P., Galián, J., Serrano, J., Moritz, R.F.A. (2002) Microsatellite analysis of non-migratory colonies of Apis mellifera iberica from southeastern Spain. J. Zool. Syst. Evol. Res. 40, 164-168

De la Rúa, P., Hernandez-Garcia, R., Jiménez, Y., Galián, J., Serrano, J. (2005) Biodiversity of Apis mellifera iberica (Hymenoptera: Apidae) from northeastern Spain assessed by mitochondrial analysis. Insect Syst. Evol. 36, 21-28

De la Rúa, P., Galián, J., Pedersen, B.V., Serrano, J. (2006) Molecular characterization and population structure of Apis mellifera from Madeira and the Azores. Apidologie 37, 699-708

De la Rúa, P., Radloff, S., Hepburn, R., Serrano, J. (2007) Do molecular markers support morphometric and pheromone analyses? A preliminary case study in Apis mellifera populations of Morocco. Arch. Zootec. 56, 33-42

Excoffier, L., Laval, G., Schneider, S. (2005) Arlequin (version 3.0): an integrated software package for population genetics data analysis. Evol. Bioinforma. 1, 47-50

Franck, P., Garnery, L., Solignac, M., Cornuet, J.M. (1998) The origin of west European subspecies of honeybees (Apis mellifera): new insights from microsatellite and mitochondrial data. Evolution 52, 1119-1134

Franck, P., Garnery, L., Celebrano, G., Solignac, M., Cornuet, J.M. (2000) Hybrid origins of honey bees from Italy (Apis mellifera ligustica) and Sicily (A. m. sicula). Mol. Ecol. 9, 907-921

Franck, P., Garnery, L., Loiseau, A., Oldroyd, B.P., Hepburn, H.R., Solignac, M., Cornuet, J.M. (2001) Genetic diversity of the honey bee in Africa: microsatellite and mitochondrial data. Heredity 86, 420-430

Garnery, L., Solignac, M., Celebrano, G., Cornuet, J.M. (1993) A simple test using restricted PCRamplified mitochondrial DNA to study the genetic structure of Apis mellifera L. Experientia 49, 1016-1021

Garnery, L., Mosshine, E.H., Oldroyd, B.P., Cornuet, J.M. (1995) Mitochondrial DNA variation in Moroccan and Spanish honey bee populations. Mol. Ecol. 4, 465-471

Garnery, L., Franck, P., Baudry, E., Vautrin, D., Cornuet, J.M., Solignac, M. (1998) Genetic diversity of the west European honey bee (Apis mellifera mellifera and $A . m$. iberica). I. Mitochondrial DNA. Genet. Sel. Evol. 30, S31-S47

Kandemir, I., Kence, M., Sheppard, W.S., Kence, A. (2006) Mitochondrial DNA variation in honey bee (Apis mellifera L.) populations from Turkey. J. Apic. Res. 45, 33-38 
Miguel, I., Iriondo, M., Garnery, L., Sheppard, W.S., Estonba, A. (2007) Gene flow within the M evolutionary lineage of Apis mellifera: role of the Pyrenees, isolation by distance and post-glacial recolonization routes in the western Europe. Apidologie 38, 141-155

Miguel, I., Baylac, M., Iriondo, M., Manzano, C., Garnery, L., Estonba, A. (2011) Both geometric morphometric and microsatellite data consistently support the differentiation of the Apis mellifera $M$ evolutionary branch. Apidologie 42, $150-161$

Peakall, R., Smouse, P.E. (2006) GENALEX 6: genetic analysis in Excel. Population genetic software for teaching and research. Mol. Ecol. Notes 6, 288-295

Pinto, M.A., Munoz, I., Chavez-Galarza, J., De la Rúa, P. (2012) The Atlantic side of the Iberian Peninsula: a hot-spot of novel African honey bee maternal diversity. Apidologie 43, 663-673

Rand, D.M. (2001) The units of selection on mitochondrial DNA. Annu. Rev. Ecol. Syst. 32, 415-448

Rice, W.R. (1989) Analyzing tables of statistical tests. Evolution 43, 223-225

Rortais, A., Arnold, G., Alburaki, M., Legout, H., Garnery, L. (2011) Review of the DraI COI-COII test for the conservation of the black honeybee (Apis mellifera mellifera). Conserv. Genet. Resour. 3, 383-391
Ruttner, F. (1988) Biogeography and taxonomy of honey bees. Springer, Berlin

Schneider, S.S., DeGrandi-Hoffman, G., Smith, D.R. (2004) The African honey bee: factors contributing to a successful biological invasion. Annu. Rev. Entomol. 49, 351-376

Shaibi, T., Muñoz, I., Dall'Olio, R., Lodesani, M., De la Rúa, P., Moritz, R.F.A. (2009a) Apis mellifera evolutionary lineages in Northern Africa: Libya, where orient meets occident. Insectes Soc. 56, 293-300

Shaibi, T., Fuchs, S., Moritz, R.F.A. (2009b) Morphological study of honeybees (Apis mellifera) from Libya. Apidologie 40, 97-105

Smith, D.R., Palopoli, M.F., Taylor, B.R., Garnery, L., Cornuet, J.M., Solignac, M., Brown, W.M. (1991) Geographical overlap of two mitochondrial genomes in Spanish honeybees (Apis mellifera iberica). J. Hered. 82, 96-100

Walsh, P.S., Metzger, D.A., Higuchi, R. (1991) Chelex 100 as a medium for simple extraction of DNA for PCRbased typing from forensic material. Biotechniques 10, 506-513

Whitfield, C.W., Whitfield, C.W., Behura, S.K., Berlocher, S.H., Clark, A.G., Johnston, J.S., Sheppard, W.S., Smith, D.R., Suarez, A.V., Weaver, D., Tsutsui, N.D. (2006) Thrice out of Africa: ancient and recent expansions of the honey bee, Apis mellifera. Science 314, 642-645 